\title{
Proposal to Improve Employability and Facilitate Entrepreneurship among Graduates of the Master's Degree in Institutional Translation of the University of Alicante
}

\begin{abstract}
The aim of this article is to describe the strategies included in our proposal to improve employability and facilitate entrepreneurship among graduates of the Master's Degree in Institutional Translation. Firstly, this paper takes as a starting point the survey data collected by the Technical Unit for Quality Assessment (UTC) at the University of Alicante. This data shows the evaluation done by the graduates of the Master's Degree in Institutional Translation on the competences preparing them for graduate labour market outcomes and entrepreneurship. Secondly, it explains the different curricular and extracurricular activities, as well as elective subjects, which are either being carried out at the moment or to be implemented in the future, so that students can develop the competences that the translator's profession requires. The paper also mentions the role played by each institutional party involved in this collaborative action and proposes measures to consolidate and further develop the initiative.
\end{abstract}

\section{Keywords}

employability; entrepreneurship; translation studies; curricular activities; extracurricular activities

\section{Introduction}

Over the past few decades, employability among graduates has become increasingly important, and it has gone hand in hand with the development of the convergence of the European university systems. As a matter of fact, the European Higher Education Area (EHEA) considers the connection between university education and the labour market to be the central element of its framework. Protected by the EHEA framework, article 9 of the University Student Statue (Real Decreto [Royal Decree] 1791/2010) includes the master's student right to receive personalized guidance and mentoring in order to facilitate academic performance, the preparation for future professional activities, or the initiation to research. Given this new situation, universities will play a leading role in the building of new competences, allowing graduates to adapt to the new realities of the ever-growing global labour market. These professional competences are related to both the access to the labour market and the acquisition of entrepreneurial competences. In this latter sense, taking into account the new realities of the translation and interpreting field, García (2000) states that "entre el abanico de salidas profesionales que ofrecen los estudios de TeI [...], la creación de una agencia de traducción e interpretación se presenta como una potencial alternativa" [among the wide range of career opportunities offered by the degree in Translation and Interpreting, setting up a translation and interpreting agency is a potential alternative] as quoted in Gieure (2018: 336).

Hence, this paper is focused on employability and entrepreneurship in the context of the Master's Degree in Institutional Translation, which is an e-learning programme, offered by the University of Alicante (UA). It takes as a starting point the results of the evaluation survey done by its graduates on the abilities which prepare them for graduate labour market outcomes and

* Analia Cuadrado-Rey
Faculty of Arts
University of Alicante
E-mail: analia.cuadradorey@ua.es
Lucía Navarro-Brotons

Faculty of Arts

University of Alicante

E-mail: lucia.navarro@ua.es 
entrepreneurship. This is followed by a description of the tools and collaborative actions offered by both the University of Alicante and the Master's Degree.

Finally, a proposal to further improve employability and facilitate entrepreneurship among graduates is developed based on the results of the survey.

\section{Literature Review}

Developing the aptitudes and attitudes which improve the employability of future graduates is a challenge for universities nowadays, especially in the context of postgraduate programmes. In light of this, facilitating the acquisition of entrepreneurial competences and skills to foster entrepreneurship is also becoming an upward trend in universities around the world.

The European Qualifications Framework (European Communities 2009: 11) defines "competence" as:

\footnotetext{
the proven ability to use knowledge, skills and personal, social and/or methodological abilities, in work or study situations and in professional and personal development. In the context of the European Qualifications Framework, competence is described in terms of responsibility and autonomy.
}

In 2003, the Green Paper on Entrepreneurship in Europe was published, and it highlighted the necessity to foster competences such as creativity and innovation in order to contribute to the creation of employment and growth (European Commission 2003: 6-7). Moreover, based on these European guidelines, the Libro Blanco para el Grado de Traducción e Interpretación [White Paper for the Degree in Translation and Interpreting] written by ANECA, the National Agency for Quality Assessment and Accreditation of Spain (ANECA 2004: 82), also focuses on the necessity to develop systemic transversal competences such as creativity, innovation, initiative, entrepreneurship, and leadership. The white paper also includes the following competences: motivation to ensure quality, self-study, adaptability, knowledge of other cultures and traditions, environmental knowledge, ability to implement knowledge in practice, and project management.

In 2010, the Spanish Directorate-General for Small and Medium-sized Enterprises (Ministerio de Industria, Turismo y Comercio 2010) published El fomento de la iniciativa emprendedora en el sistema educativo en España [Promoting Entrepreneurship in the Spanish Education System], which is a comprehensive review of education policies and practices sorted by autonomous communities and aimed at developing entrepreneurial skills. Diego/Vega (2015: 62) state that this review "supuso un primer acercamiento al tratamiento que recibía la iniciativa emprendedora en el sistema educativo de aquel momento" [was the first approach to entrepreneurship in the education system at that time]. However, it explains that "no existe ningún documento estratégico que incluya la educación para el emprendimiento" [there is no strategic document including education for entrepreneurship in the Valencian Community] (Diego/Vega 2015: 74). In fact, this review also states that "no se identifican estudios de impacto ni publicaciones sobre las iniciativas de educación emprendedora puestas en marcha en esta Comunidad" [there are neither high impact papers nor publications about initiatives promoting education for entrepreneurship carried out in this community] (Diego/Vega 2015: 75).

Ironically, many scholars such as Kirby et al. (2011); Ripollés (2011); Sánchez et al. (2011) (as quoted in Gieure 2018: 328) think that universities should play a leading role both in the transfer of knowledge to society and in the development of initiative and entrepreneurial skills among students.

Moreover, the European Higher Education Area (EHEA) considers the transfer of knowledge to be as equally important as the development of competences and skills which prepare students for graduate labour market outcomes and entrepreneurship. This is not an easy task, as the everchanging needs and priorities of the labour market are difficult to predict in the short term. For instance, according to the UK's largest employer survey, more than $70 \%$ of employers expect the skills required to fill their open job positions to change throughout the year (Winterbotham et al. 2014). Therefore, universities and organisations need to work together to ensure a good match 
between the skills learnt at university and those used in the workplace. In the translation field, the survey data collected by the Technical Unit for Quality Assessment (UTC) at the University of Alicante (2018: 35) shows that "el desarrollo de estas habilidades transversales es una demanda manifiesta por parte de los responsables de Recursos Humanos de las empresas." [many Human Resources Managers at different companies have already insisted on the development of these transversal competences]. However, some authors (Bock 2003; Bolivar 2008; Corominas y Sacristán 2011, among others) think that this perspective subordinates universities to the demands of the labour market and also contradicts the main objective of universities, which is to provide a comprehensive education. In this sense, they explain that the labour market should be an important part of the educational project, but it should not condition it. Nevertheless, it is also important to remember that the main objective of university education is to train professionals. As Cifuentes Férez (2017: 198) explains, this objective "se recoge en el Documento Marco sobre la integración del sistema universitario español en el Espacio Europeo de la Educación Superior" [is included in the framework document on the integration of the Spanish university system in the European Higher Education Area]. The White Paper for the Degree in Translation and Interpreting, which has been previously mentioned, includes the systemic transversal competences in table 13 (ANECA 2004: 82) and points out that employers give priority to competences such as initiative and entrepreneurship. However, as Kelly (2000: 8) states, "la universidad debe seguir cumpliendo su papel de ofrecer formación intelectual, analítica y crítica básica" [universities must continue fulfilling their role of offering basic intellectual, analytical and critical education].

In this context, Cifuentes Férez (2017) conducted a research in order to determine the ten key competences for the employability of translators and interpreters based on the opinions of the graduates in this field. She also explains that "el sistema universitario español debe ser capaz de desarrollar en cada uno de los estudiantes las competencias propias de cada titulación, sin olvidar fomentar un conjunto de competencias genéricas, además de una serie de competencias transversales" [the Spanish university system should help students develop not only the specific competences of each degree, but also generic competences, as well as some transversal competences] (Cifuentes Férez 2017: 199). On the other hand, Álvarez Álvarez (2018) is leading a project to foster the development of professional competences in Translation and Interpreting Studies (Álvarez Álvarez et al. 2018).

In its competence framework, the European Master's in Translation network (EMT) has affirmed that "in October 2016, with future translation graduate employability firmly in mind, the EMT Board was given the remit of producing a new EMT competence framework" (EMT 2017: 2). This framework also defines five main areas of competence: language and culture, translation, technology, personal and interpersonal, and service provisions. The personal and interpersonal competence area includes all the generic skills "that enhance graduate adaptability and employability" (EMT 2017: 10), which are the following:

21. Plan and manage time, stress and workload

22. Comply with deadlines, instructions and specifications

23. Work in a team, including, where appropriate, in virtual, multicultural and multilingual environments, using current communication technologies

24. Use social media responsibly for professional purposes

25. Take account of and adapt the organizational and physical ergonomics of the working environment

26. Continuously self-evaluate, update and develop competences and skills through personal strategies and collaborative learning 
It is undeniable that our current global economic system is characterized by competitiveness and globalization. In the European Council in Lisbon (2000), the European Union said that it was aiming to become the most competitive and dynamic knowledge-based economy in the world. One of the main objectives of this summit was to promote the creation of companies (European Parliament 2000). The Coordination Office of the Master's Degree in Institutional Translation offered by the University of Alicante is aware of this situation. That's why quality assessments and indicators are being improved in our internship programmes with the aim to facilitate the connection between our students and the labour market. In this sense, methodologies such as "situated learning" (Lave/Wenger 1991; Stein 1998) and "experiential learning" (Kolb 1984) are applied in order to help students take their first steps into the labour market. Kiraly (2005: 1102-1103) explains that applying these methodologies to Translation Studies leads to "radical changes in students' relationships to their instructors, their fellow students, and the professional community, as well as in their understanding of the learning and teaching process and their own self-concept as developing professionals". As noted by Hervás et al. (2012: 6), "Las prácticas en empresas proporcionan también un aumento importante de los contactos profesionales personales, tanto en las empresas donde realizan las prácticas, como en empresas proveedoras o clientes de éstas" [internships in companies also provide a significant increase in the student's network of professional contacts, both in the companies in which the internship took place, and also in those that were suppliers or clients of these companies]. We understand these internship programmes as an opportunity for our students to transfer the acquired competences to the workplace and also reinforce them. Moreover, regarding employability, "Los estudios de seguimiento de inserción laboral de graduados universitarios [...] coinciden en que uno de los medios más eficaces para el incrementar la empleabilidad de los titulados es la realización de prácticas en empresas e instituciones" (Hervás et al. 2012: 8) [different tracer studies of graduates' labour market integration agree that carrying out internships in companies and institutions is one of the most effective means to increase the employability of graduates]. Therefore, "la realización de prácticas rompe el círculo vicioso de falta de contratación por falta de experiencia, y falta de experiencia por falta de contratación" (Hervás et al. 2012: 6) [internships break the vicious cycle of not hiring graduates due to lack of professional experience and their inability to gain experience due to lack of hiring.). As Gieure (2018: 335) states, "las prácticas en empresa [...] además, pueden despertar entre los alumnos la iniciativa empresarial, es decir, pueden fomentar el espíritu emprendedor" [students might develop initiative and entrepreneurial skills during their internships].

In this sense, it is important to create new collaboration opportunities between universities and employers or institutions related to the translation field. Different papers such as the ones written by Suárez Lantarón (2014: 278), Generalitat Valenciana/Agència Valenciana d'Avaluació i Prospectiva (2013: 135-136) or Ausín (2010: 127) agree on this matter. Therefore, it is also important to encourage research on the relationship between recent graduates and companies, as Galán-Mañas (2017) explains.

The main objective of this paper is to develop a comprehensive proposal focused on fostering competences related to employability and entrepreneurship among students, as written in European guidelines. Curricular, extracurricular and elective components will also be included in this proposal. The purpose is to promote, encourage, facilitate, and improve employability and entrepreneurship among graduates of the Master's Degree. In order to achieve this, the proposal will focus on the development of new professional competences and skills. Extracurricular activities will also be incorporated into curricular activities in a coordinated manner, and we will also make sure that all the guidance and tutoring services offered by the University of Alicante are available to students. Some educational complementary activities, such as customised counselling interviews and career guidance courses, which include job search techniques, CV, Europass Curriculum, and cover letter writing advice, and tips on how to successfully pass a job interview, will be also carried out in order to make students adapt to the realities of the workplace. 
Therefore, this initiative is aimed at combining employability with the entrepreneurial skills of recent graduates.

\section{Methodology}

The University of Alicante has a Technical Unit for Quality Assessment (UTC) which collected survey data showing the evaluation done by the graduates of each Master's Degree offered by the Faculty of Arts on the competences which prepare them for graduate labour market outcomes and entrepreneurship. Taking this data as a starting point, we selected the evaluation which participants did on certain competences according to their relevance and development throughout the Master's Programme in Institutional Translation.

\subsection{Context and participants}

The students of the Master's Degree in Institutional Translation of the University of Alicante during the academic years of 2013-14, 2014-15, 2015-16, and 2016-17 are the target population of the current paper. There are 149 students in total, but only 133 carried out the survey.

The sociodemographic characteristics of the sample have the following gender and age variables: the target population is mostly female with $79 \%$ women and $21 \%$ men; the distribution by age of the surveyed population is fairly uniform: $37.1 \%$ are up to 26 years old, $21 \%$ are between 27 and 30 and, finally, $41.9 \%$ are more than 30 years old.

\subsection{Instruments}

The sampling was done with a closed-ended and standardized computer-assisted telephone survey carried out using a system called CATI (Computer Assisted Telephone Interview). Three laws protect the access of personal data in order for the University of Alicante to conduct the telephone survey: (1) Spanish Organic Law 15/1999, of December 13, for the Protection of Personal Data (Ley Orgánica 15/1999 de 13 de diciembre de Protección de Datos de carácter Personal); (2) Article 6.1.e) of the General Data Protection Regulation 2016/679 of the European Parliament and the Council on studies carried out by university bodies, in the exercise of the functions of the University itself at an institutional level, for "the performance of a task carried out in the public interest or in the exercise of official authority vested in the controller"; (3) Spanish Organic Law 3/2018, of December 5, on Data Protection and Guarantee of Digital Rights (article 26).

During the survey, personal data was not transferred to any companies or institutions outside the University of Alicante. In fact, it was the University itself, through its own Technical Unit for Quality Assessment (UTC), the one that carried out the fieldwork for the survey. Moreover, anonymity and confidentiality were guaranteed when processing the data and the information provided by the person surveyed during the interview. Therefore, the University of Alicante worked in conformity with all the principles of confidentiality and data privacy.

Thanks to this system, the results were quickly and efficiently obtained, as application and recording times were reduced. The CATI also collected the results at a lower cost because the target population had no accessibility problems even though there was a significant geographical distribution among them. This geographical distribution is due to the fact that the Master's Degree is an e-learning programme.

\subsection{Data collection procedure}

This paper uses a quantitative methodological approach and its primary data was collected with a survey. A random sampling with proportional allocation was used. In order to compute the final sampling error and the weighting coefficient, the current structure of the seven faculties of the University of Alicante offering Official Master's Degrees was taken into account: Faculty of Economics and Business Sciences, Faculty of Science, Faculty of Health Sciences, Faculty of 
Law, Faculty of Education, Faculty of Arts, and Polytechnic School (EPSA). This methodology has an additional advantage because it reduces the data collection time. Moreover, it shows the evaluation on the acquired competences done by the graduates who studied the Master's Degree in Institutional Translation in the past four academic years.

The survey, made up of closed-ended, multiple-choice, and evaluation questions, focuses on the following questions: different career paths at the end of the Master's Degree; graduates' participation in the labour market; the ways in which graduates found their first paid job; main characteristics of their current job position; their evaluation of their studies and the acquired competences and skills; the curricular and extracurricular activities carried out; mobility options; internships, and entrepreneurship.

This fieldwork was carried out from May 28 to June 20, 2018. In order to facilitate the understanding of the data, the obtained results are presented using graphs.

\section{Findings}

Five graphs showing the obtained results are analysed below. These results include the evaluation of the internship programmes offered in the Master's Degree in Institutional Translation and also of the employability, competences, and entrepreneurship of the graduates of the Master's Programme. The analysis of the data provides unbiased information to create our proposal and hence to meet the needs of the students of our Master's Degree.

Once the data collection was carried out, the results were classified in two different sections. One section focuses on employability and the other, on entrepreneurship. Regarding employability, this paper presents results on the type of internships carried out by the students in the Master's Degree in Institutional Translation, the level of student satisfaction with their internships, and the degree of importance which students placed on their internship when it comes to finding a job. On the other hand, regarding entrepreneurship, this paper presents results on the most important competences in the course of the graduates' work and also on the likelihood that they will start their own company in the future.

\subsection{Findings on employability}

Curricular internships in companies are mandatory and are therefore established as a subject within the syllabus of the Master's Degree in Institutional Translation. However, students who are able to prove that they have already carried out a job related to the specialty of the Master's Programme can apply for credit recognition. Extracurricular internships are optional and can be carried out by any student. Figure 1 shows the results obtained about the type of internship (curricular or extracurricular) carried out by the students of the Master's Degree. There is a significant difference between the percentage of curricular internships, which exceeds $80 \%$, compared to the percentage of extracurricular internships, which only reaches $15 \%$. 


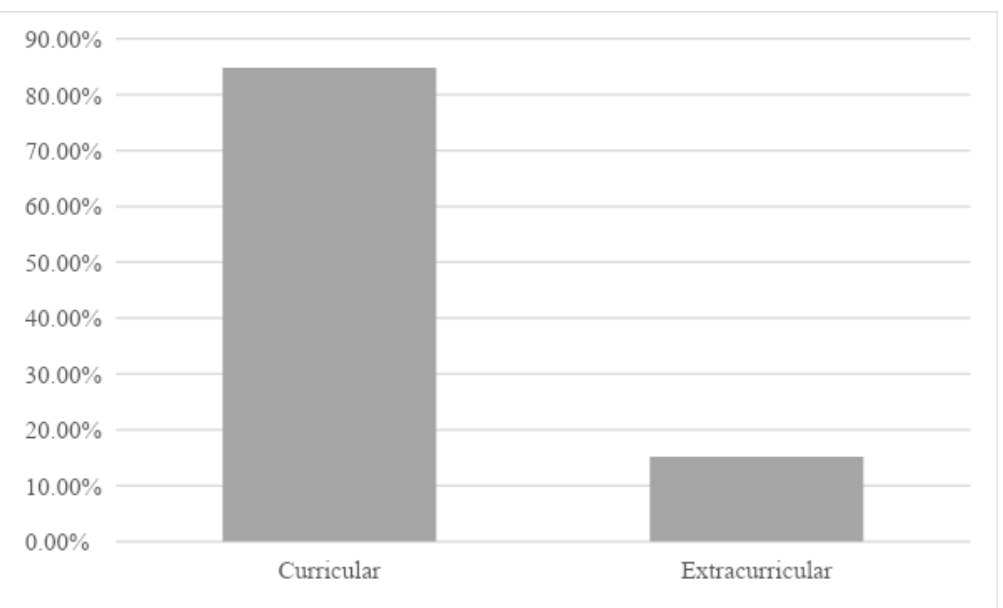

Figure 1. Type of internship carried out in the Master's Degree

Figure 2 shows the level of student satisfaction with the internships carried out during their Master's Degree. $61,40 \%$ of students were very satisfied or satisfied; $30,10 \%$ were dissatisfied or very dissatisfied.

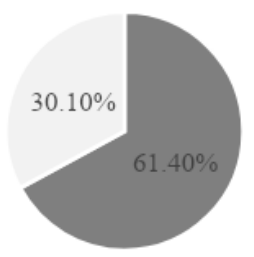

- Very satisfied or satisfied Dissatisfied or very dissatisfied

Figure 2. Level of student satisfaction with the internship

Figure 3 shows the degree of importance which students placed on their internship when it comes to finding a job. Taking into account the high and medium degrees of importance, it can be affirmed that $87 \%$ of the students value in a very positive way internships as a means of finding a job once the Master's Degree is finished. Only slightly more than $10 \%$ of students think that the degree of importance of the internships is low, and nobody considers them to be unimportant.

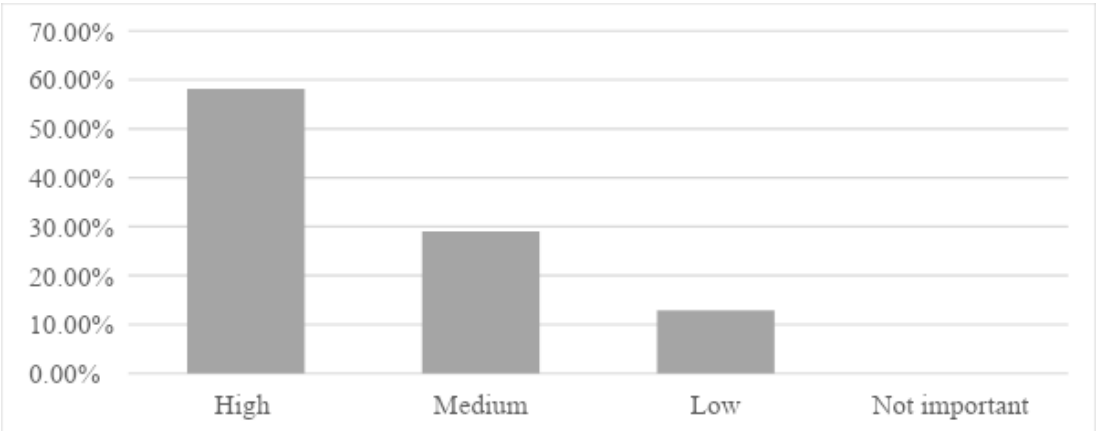

Figure 3. Degree of importance of internships as a means of finding a job 


\subsection{Findings on entrepreneurship}

Graduates evaluated the following competences: analysis and synthesis; self-study; teamwork; public speaking; communication in mother tongue and foreign languages; basic computer skills; initiative and entrepreneurship; social skills; leadership; resource planning and management; decision-making; and critical thinking.

In this sense, the students of the Master's Degree in Institutional Translation think that the most important competences in the course of their work (in a scale of 1 - not important - to 5 -very important) are the following (Table 1):

\begin{tabular}{lc}
\hline Competences & Scale \\
\hline Communication in mother tongue and foreign languages & 4.92 \\
Resource planning and management & 4.81 \\
Self-study & 4.80 \\
Basic computer skills & 4.79 \\
Decision-making & 4.71 \\
Critical thinking & 4.58 \\
Analysis and synthesis & 4.48 \\
Social skills & 4.44 \\
Teamwork & 4.35 \\
Initiative and entrepreneurship & 4.31 \\
Leadership & 4.26 \\
Public speaking & 4.13 \\
\hline
\end{tabular}

Table 1 . Competences evaluated by graduates

However, when students were asked to what extent these competences were developed during the Master's Degree (in a scale of 1 - not developed - to 5 - highly developed -), there is a mismatch between the importance given to each competence and the degree to which they were developed in university. In every case, the level of development of these competences during the Master's Degree always obtains lower scores than their level of importance for graduates in current or future professional activities. In fact, the biggest difference can be seen in both initiative and critical thinking. According to the graduates in the Master's Degree, the importance of critical thinking was 4.31 , but its development at university only obtained 3.39. Leadership also obtained 4.26 in importance, but only 3.33 in development.

Figure 4 shows both dimensions of competences (importance and development). Therefore, the differences between the evaluation scores of both the level of importance which each competence has in the labour market, and their level of development at university can be observed. 


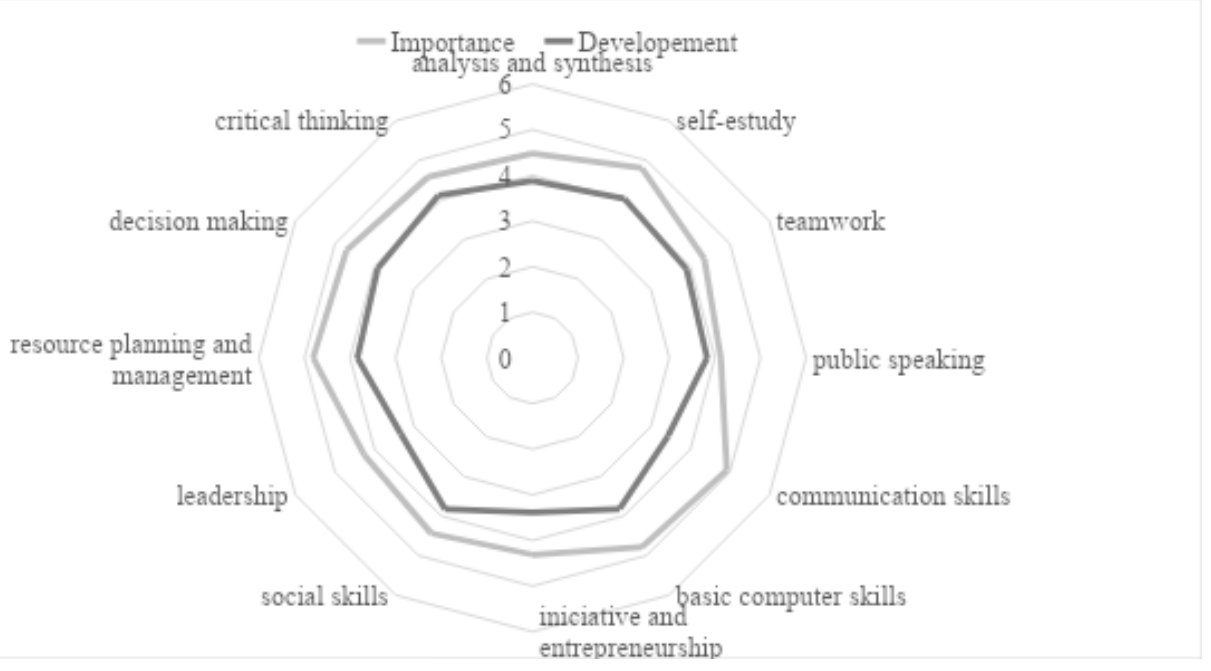

Figure 4. Importance and development of competences in the Master's Degree in Institutional Translation

In 2010, the Technical Unit for Quality Assessment (UTC) of the University of Alicante published a report on the opinion that employers have about the competences and skills of the graduates from the University of Alicante. This report stated that "la mayoría de los déficits formativos detectados hacían referencia no tanto a contenidos teóricos concretos, sino al aprendizaje de técnicas y herramientas para la inmersión en el mundo laboral y de preparación sobre algunos contenidos prácticos" [most of the educational deficiencies detected in the Master's Degree were not related to specific theoretical content, but to the skills and techniques needed in order for students to take their first steps into the labour market and to carry out practical tasks]. Moreover, it already mentioned "la falta de formación básica para el autoempleo (autónomo o emprendedor)" [the lack of basic education for entrepreneurship, including both freelancers or entrepreneurs] and "la falta de iniciativa de los propios titulados y tituladas universitarios a la hora de convertirse en emprendedores y crear su propia empresa" [the lack of initiative that graduates at university have when it comes to starting their own company] (UTC 2010: 36)

Figure 5 shows the results of the survey on the likelihood that the graduates of the Master's Degree will start their own company in the future. When asked about this likelihood, 40\% answered that it was very likely, $13 \%$ said it was likely; $13 \%$ said it was unlikely, and $34 \%$ said it was very unlikely. 


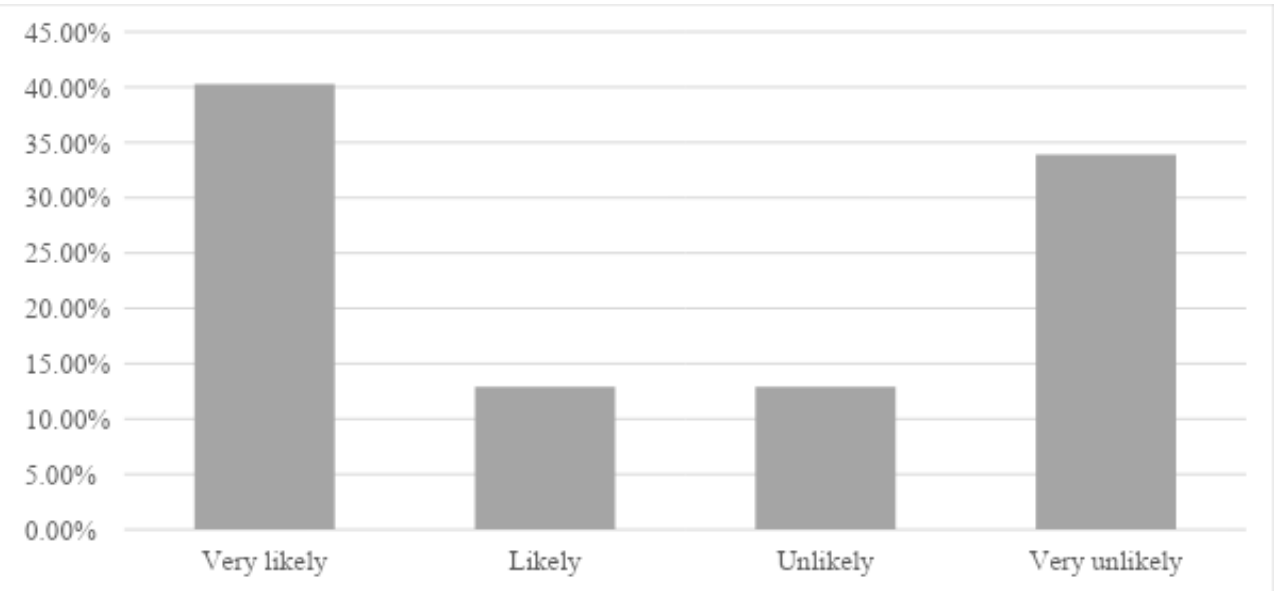

Figure 5. Likelihood that the graduates of the Master's Degree in Institutional Translation will start their own company in the future

Therefore, the proposal explained in the next section was motivated by a wish to address the fact that employers state that $34 \%$ of the graduates in Translation have the profile of a freelance translator (ANECA 2004: 70). This is mostly a solo job, as $26 \%$ of translation companies have only one employee according to a paper analysing the translation sector in Spain (Rico Pérez/ García Aragón 2016: 55). Therefore, in order to carry out this job, it is necessary to develop entrepreneurial competences such as leadership, initiative, and entrepreneurship. However, they are still considered to be the least important and also the least developed competences in the Master's Degree in Institutional Translation. The proposal is also aimed at addressing the low percentage of students who carried out extracurricular internships, and at increasing both the level of student satisfaction with the internship programmes and the likelihood that graduates will start their own company in the future.

\section{Discussion}

\subsection{Proposal}

As the findings of the survey have already been analysed, the different tools offered by the Master's Degree in Institutional Translation in order to improve employability and facilitate entrepreneurship are explained below. Subsequently, a proposal to implement these tools is also described in order to foster the development of professional competences such as initiative, entrepreneurship, and leadership. This proposal is aimed both at improving the tools already used in the Master's Degree and also at complementing them with the different opportunities to facilitate entrepreneurship among graduates offered by the University of Alicante.

\subsection{Tools offered by the Master's Degree in Institutional Translation}

The Master's Degree in Institutional Translation contains four different curricular and extracurricular tools and activities which are focused on business training and job placement. The first tool offered in the Master's Degree is the course on Codes of Conduct and Professional Practice (6 ECTS credits), which consists of a review of translation career opportunities and learning needs as well as an analysis of codes of conduct, taxes, and the professional activities of translators and interpreters. The course also addresses the current situation of professional translators living both in Spain and abroad: certification requirements, social prestige, associations, etc. It also introduces basic professional computer tools to translate and manage different translation projects. Finally, this course also explains different research techniques and strategies. The professors in charge 
of teaching this subject also belong to different areas of knowledge: some are specialized in English, and others in French. This means that there is a fair representation of the two language combinations offered in the Master's Degree. The curriculum has a tripartite structure, consisting of a first general module ( 15 credits), a second specialized module (30 credits: 20 credits core courses and 10 credits elective courses) in the chosen language combination (English-Spanish or French-Spanish), and a third module (15 credits) dedicated to internships (9 credits) and a Master's thesis (6 credits).

The second tool offered by the Master's Degree is the opportunity for students to carry out curricular internships. It is a mandatory subject which is considered essential in order to meet the needs of future graduates and prepare them for graduate labour market outcomes. This mandatory subject comprises a total of 225 hours (9 ECTS credits). This is also equivalent to translating 15,000 words related to legal, economic, and administrative translation. These internships are always carried out in translation agencies or organizations which at least have a department of translation and interpreting, which guarantees that the student is being mentored by an industry professional. These internships are beneficial learning experiences, as they allow students to know both the profiles in the translation and interpreting field that are most sought after by companies today, and also the most required skills if they want to become future translators. Finally, internships also offer students the possibility to evolve as professionals and enter the professional translation market. After finishing their internships, students write a ten-page report focusing on the following topics: motivation and previous objectives, brief introduction of the institution or company, preparation for the internship, tasks and work carried out during the internship, work organization, personal evaluation of the student's performance, and evaluation of the internship. Moreover, students must complete an evaluation survey carried out through the UACloud platform of the University of Alicante coordinated by the Technical Unit for Quality Assessment (UTC). This survey is also carried out for the rest of the Master's subjects.

These internship programmes have been developed according to the Real Decreto (Royal Decree) 592/2014, which regulates internships for university students in order to facilitate employability among future graduates and also to foster competences such as entrepreneurship, creativity, and innovation.

The third tool provided by the University of Alicante is the Double Degree Programme which allows students to obtain both the Master's Degree in Institutional Translation (UA), and the Postgraduate Mention "Traduction et Interprétation" (Parcous "Traducteur comercial et juridique", Jean Moulin Lyon 3) upon completion of 71 credits. Students admitted at the University of Alicante are offered the possibility to spend the academic year in Lyon, where they will attend face-to-face lessons while taking some online modules offered by the University of Alicante. They also carry out their internship in France, which comprises a total of 30 ECTS credits.

Finally, there are seminars conducted by prestigious professionals and entrepreneurs who help students develop their professional skills and also prepare them for graduate labour market outcomes.

\subsection{Measures to improve the tools offered by the Master's Degree in Institutional Translation}

\subsubsection{Personalized guidance and mentoring}

In addition to the curricular and extracurricular courses and tools explained above, the Master's Degree in Institutional Translation offers different elective activities and tools focused on student mentoring and guidance. Taking into account the special characteristics of the e-learning environment where lessons are developed, both face-to-face and remote mentoring become key tools to track student progress during the Master's Degree. In this context, our students have access to different computer tools which facilitate the interaction between professors and students 
such as the chat feature in the Moodle platform or the online tutorial feature in the UACloud platform of the University of Alicante. Using this tutorial feature, students can select the face-toface or electronic tutoring hours which suits them best to contact their professors.

Regarding curricular internships, we have created a questionnaire, which students fill during the first weeks of the Master's Degree, in order to know the needs and different profiles of each student. It is a dynamic tool which let us know first-hand the expectations and concerns of our students as well as their previous work experience in the translation and interpreting field. Students are firstly asked to read the teaching guide of the subject and then to choose the type of internship they would like to do. Then, students have to choose if they want to carry out an internship related to the translation field and coordinated by the Master's Degree, or if they prefer to carry it out in the translation department (or any related departments) of a company or institution. If they choose the second option, they are asked to mention a company where they would like to do their internship, as we need to confirm if an agreement between the university and that company is needed.

When students finish the entire questionnaire, an accurate picture of each student is provided, and then we can assess the information needs of each student in the Master's Degree.

Once the analysis of the answers given by each student has been carried out, we propose to offer personalized mentoring and guidance using the online and/or face-to-face tutoring hours, and the chat feature in the Moodle platform in order to maximize these two resources and improve student satisfaction. By doing this, students would develop their ability to detect their weaknesses and professors could help them find different strategies to overcome them. Moreover, personalized mentoring is likely to be of special relevance for those students showing interest in entrepreneurship, as professors, who act as a link between students and professionals, will help them analyse and identify viable career paths in entrepreneurship.

\subsubsection{Extracurricular internships and additional training}

The survey data collected shows the impact of internships on student professional development. The data on the age range of the surveyed students also shows that approximately $40 \%$ of these students are younger than 26. Both the positive evaluation on internships given by our students and the data on their age range reflect the importance of internships as the first exposure of students to the translation and interpreting market. In fact, this clearly suggests that internships act as a bridge between university and professional life. However, the low rate of students who carry out extracurricular internships (as shown in the findings section) leads us to include different information campaigns and strategies in our proposal. These campaigns and strategies are aimed at making students understand the relevance of extracurricular internships for their future professional lives and also at explaining the different scholarships for internships offered by the University of Alicante. There are also several internship opportunities and activities offered by GIPE (Gabinete de Iniciativas para el Empleo), which is the service of the University of Alicante managing employment initiatives, as well as the UA Emprende Project, and we should make sure that our students are aware of each of them.

Extracurricular internships. One of the main objectives of our proposal to improve interaction with the students of the Master's Degree is to let them know about the different available internship opportunities related to their specialty. In this context, it is important that students are aware of the possibility of complementing their curricular internships with extracurricular internships in order to get more work experience. Despite also being internships determined by agreement between the university and collaborating companies and institutions, extracurricular internships don't appear in any subject syllabus. Therefore, we should explain the possibility to carry out these internships to our students in more detail so that they can decide whether to take this opportunity or not.

Scholarships. The University of Alicante offers scholarships both for internships carried out in the Faculty of Arts and also for international internships, thanks to programmes such as Erasmus ${ }^{+}$. 
These scholarships offer students the possibility to carry out paid internships in the translation field in an English or French-speaking country in order to receive intercultural training. As Kolb (1984: 38) states, "learning is the process whereby knowledge is created through the transformation of experience". If Experiential Learning is a clear advantage for translators, these internships will help them acquire new skills and competences. Therefore, this experience fosters competences such as teamwork in a multilingual and multicultural environment, and develops independence and adaptability after a process of reflective observation, abstract conceptualization, and active experimentation. Moreover, it is important to remember that "professionalising the learning environment, [...], can lead to increased employability after graduation." (INSTB 2017: 88)

Internship opportunities and activities offered by GIPE (Gabinete de Iniciativas para el Empleo). Since its creation in 1992, this service is focused on facilitating job placement for students and graduates of the University of Alicante in those areas related to their studies. It also offers tools and public employment programmes aimed at improving job opportunities for university students. GIPE, which has been an authorized placement agency since 2012, consists of the following areas: employment area, internships area, professional training and mentoring area, and the University Observatory of Labour Insertion.

The employment area collects and actively looks for job offers by carrying out events, visiting companies, and negotiating cooperation agreements to promote employment with different institutions and private companies. This area is also aimed at connecting companies and students. This way, companies get to know future professionals and students have an opportunity to offer their professional skills to these companies.

The professional training and mentoring area organizes and gives brief courses on different topics including professional and personal development, $\mathrm{CV}$ creation, and tips and tools to help students succeed in their job search. This area also organizes different activities focused on connecting companies to university students such as talks given by public and private companies, careers fairs such as the "Maratón de Empleo y Autoempleo" [marathon of employment and selfemployment], and personnel selection processes. Finally, the University Observatory of Labour Insertion is aimed at tracking the different career paths followed by graduates of the University of Alicante.

UA Emprende. In addition to the GIPE initiative, the Office of the Vice-Rector for Research and Innovation and the Office of the Vice-Rector for Students Affairs also developed a project called UA Emprende, which is intended for research staff, students, and graduates of the University of Alicante. Its main goal is to increase the number of innovative and sustainable companies created by students and graduates of the University of Alicante. In order to achieve this goal, this project focuses on fostering entrepreneurship among students and graduates, on developing business ideas, and on driving different business initiatives. The tool UA Emprende: lab, which is focused on business ideas development and acceleration, was born within this project. This tool gives students the possibility to take part in dynamic workshops in order to develop their entrepreneurial skills. It also prepares students to participate in the Impulso competition, as it develops their analytical skills so that they can determine the technical and financial feasibility of their project: business plan, business model, etc. These tools are essential to successfully initiate and develop a business idea.

Taking advantage of the tools mentioned above, the Coordination Office of the Master's Degree proposes to promote the development of learning itineraries that help our students and graduates discover what opportunities for business creation and entrepreneurship exist in the translation and interpreting field. This way, students would develop innovative business ideas and start their own projects. Moreover, as the Master's Dissertation is aimed at reflecting on the skills acquired during the programme, more specifically during internships, we propose to offer our students the possibility to carry out a business plan for their Master's Dissertation, which would let them learn and develop entrepreneurial compentences. 


\section{Conclusion}

Although students evaluated entrepreneurial competences with a lower score than other competences such as communication or resource planning and management, this survey carried out by the Technical Unit for Quality Assessment (UTC) shows that there is a strong likelihood that graduates will create their own business in the future after the completion of the Master's Degree in Institutional Translation. This fact highlights the importance of our proposal, which is aimed both at improving the existing tools and also at introducing new tools offered by the University of Alicante.

Therefore, the translator training should be focused on the development of professional competences which facilitate employability, with special emphasis on the development of entrepreneurial skills.

Encouraging and strengthening cooperation agreements between the University of Alicante and employers in the translation field will help the Coordination Office of the Master's Degree in Institutional Translation adapt its learning itineraries and programmes to the new characteristics, needs, and trends of the labour market.

\section{References}

Álvarez Álvarez, Susana 2018: Objetivo: Empleabilidad. El desarrollo de competencias profesionales en los Estudios de Traducción e Interpretación. Valladolid: Universidad de Valladolid. [online]. http:/uvadoc.uva.es/ handle/10324/30978 (accessed 25 May 2019).

ANECA 2004: Libro blanco. Título de Grado en Traducción e Interpretación. [online]. http://www.aneca.es/var/ media/150288/libroblanco_traduc_def.pdf(accessed 20 May 2019).

Ausín Andrés, Eva 2010: Empleabilidad del universitario: orientación del aprendizaje basado en competencias. $\mathrm{PhD}$ thesis, Universidad de Deusto. [online]. http://dkh.deusto.es/comunidad/thesis/recurso/empleabilidad-deluniversitarioorientacion-del/79af071b-1 fcc-42a4-ad78-7acb4cfd9e6d (accessed 21 May 2019).

Bock, Derek 2003: Universities in the marketplace: the commercialization of Higher Education. Princenton: University Press.

Bolivar, Antonio 2008: El discurso de las competencias en España: educación básica y educación superior. In Revista de docencia universitaria, monográfico 2, 1-23.

Cifuentes Férez, Paula 2017: Las diez competencias fundamentales para la empleabilidad según egresados, profesorado y profesionales de la traducción y la interpretación. In Quaderns 24, 197-216.

Corominas, Albert/Sacristán, Vera 2011: La encrucijada estratégica de la universidad pública española. In Revista de Educación 355, 57-81.

Diego Rodríguez, Iván/Vega Serrano, Jose Antonio 2015: La educación para el emprendimiento en el sistema educativo español. Año 2015. Madrid: Ministerio de Educación, Cultura y Deporte. [online]. https://www.sel-gipes.com/ uploads/1/2/3/3/12332890/2016_ _ ue - entrepreneurship_education_at school_in_europe_sp.pdf (accessed 28 April 2019).

EMT. Competence framework 2017. European Commission [online]. https://ec.europa.eu/info/sites/info/files/emt competence_fwk_2017_en_web.pdf(accessed 27 April 2019).

European Commission 2003: El libro verde: el espiritu empresarial en Europa. Brussels: Publicaciones de la DG Empresa.

European Communities 2009: El Marco Europeo de cualificaciones para el aprendizaje permanente (EQF-MEC). Luxemburg: Oficina de Publicaciones Oficiales de las Comunidades Europeas. [online]. https://ec.europa.eu/ ploteus/sites/eac-eqf/files/broch_es.pdf (accessed 29 April 2019).

European Parliament 2000: Consejo Europeo de Lisboa 23 y 24 de Marzo 2000. Conclusiones de la presidencia. [online]. http://www.europarl.europa.eu/summits/lis1_es.htm?textMode=on (accessed 5 May 2019).

Galán-Mañas, Anabel 2017: Programa para la mejora de la empleabilidad de los egresados en traducción e interpretación. Un estudio de caso. In Conexão Letras 12 (17), 153-171.

Generalitat Valenciana/Agència Valenciana d'Avaluació i Prospectiva. Libro Verde de la Empleabilidad de los titulados universitarios de la Comunitat Valenciana 2013. [online]. http://libroverdeempleabilidad.avap.es/dosc/ LibroVerdeEmpleabilidad.pdf (accessed 06 May 2019). 
Gieure, Clara 2018: La formación emprendedora para traductores e intérpretes: implicaciones para el sector. In Valero Cuadra, Pino/Cuadrado-Rey, Analía/Carrión González, Paola (eds.), Nuevas tendencias en traducción: fraseología, interpretación, TAVy sus didácticas. Berlin: Peter Lang, 327-358.

Hervás, Antonio/Ayats, José Carlos/Desantes, Rafael/Juliá, Juan-Francisco 2012: Las prácticas en empresa como uno de los ejes vertebradores de la empleabilidad. In Revista iberoamericana de educación superior 3 (8), 3-33.

INSTB 2017: Professionalising the Curriculum and Increasing Employability Through Authentic Experiential Learning: The Cases of INSTB. In Current Trends in Translation Teaching and Learning E 4, 78-111.

Kelly, Dorothy 2000: La traducción y la interpretación en España hoy: perspectivas profesionales. Granada: Comares.

Kiraly, Don 2005: Project-Based Learning: A Case for Situated Translation. In Meta 50 (4), 1098-1111.

Kolb, David A. 1984: Experiential Learning: Experience as the Source of Learning and Development. Englewood Cliffs, N.J.: Prentice-Hall, Inc.

Lave, Jean/Wenger, Etienne 1991: Situated learning. New York: Cambridge.

Ministerio de Industria, Turismo y Comercio (2010): El fomento de la iniciativa emprendedora en el sistema educativo en España: recopilación de políticas y prácticas. Junio de 2010. Madrid, Spain: Ministerio de Industria, Turismo y Comercio. [online] http://www.ipyme.org/publicaciones/fomentoiniciativaemprendedora.pdf (accessed 20 May 2019).

Real Decreto 1791/2010, de 30 de diciembre, por el que se aprueba el Estatuto del Estudiante Universitario. Boletín Oficial del Estado de 31 de diciembre de 2010, 109353-109380.

Rico Pérez, Celia/García Aragón, Álvaro. Análisis del sector de la traducción en España: 2014-2015. [online]. http:// abacus.universidadeuropea.es/handle/11268/5057 (accessed 23 October 2019).

Stein, David 1998: Situated learning in adult education. ERIC Digest 195. [online]. https://files.eric.ed.gov/fulltext/ ED418250.pdf (accessed 20 October 2019).

Suárez Lantarón, Belén S. 2014: La empleabilidad en la universidad española. In Journal for Educators, Teachers and Trainers 5 (2), 272-286.

Unidad Técnica de Calidad 2010: Competencias y habilidades del alumno egresado de la Universidad de Alicante 2010. La visión de los empleadores. [online]. https://utc.ua.es/es/documentos/inicio/informe-empleadores.pdf (accessed 18 May 2019).

Winterbotham, Mark/Vivian, David/Shury, Jan/Davies, Ben/Kik, Genna 2014: UK Commission's Employer Skills Survey 2013: UK Results. UK Comission for Employment and Skills. [online]. https://assets.publishing.service.gov. uk/government/uploads/system/uploads/attachment_data/file/303495/ukces-employer-skills-survey-13-executivesummary-81.pdf (accessed 20 May 2019). 